\title{
Reproductive system of the male hermit crab Clibanarius sclopetarius: gonopore, spermatophore, and spermatozoal morphologies
}

\author{
Nathália M. Santos, Fernando L. Mantelatto* \\ Laboratory of Bioecology and Crustacean Systematics (LBSC), Department of Biology, Faculty of Philosophy, \\ Sciences and Letters of Ribeirão Preto (FFCLRP), University of São Paulo (USP), Av. Bandeirantes, 3900, CEP 14040-901, \\ Ribeirão Preto, São Paulo, Brazil
}

\begin{abstract}
In the present study, the morphology and biometry of the spermatophores of the western Atlantic hermit crab Clibanarius sclopetarius (Herbst, 1796) are described, and the results are placed in the context of the Paguroidea, in particular the Diogenidae. Individuals of C. sclopetarius were sampled from a human-impacted mangrove area of southern Brazil. The male reproductive system was removed, measured and analyzed using stereoscopic, light, transmission-electron and scanning-electron microscopy. This system is composed of lobular testes connected to the vas deferens, and gonopores with membranous coverage. The mature spermatophore consists of a spherical pack that stores sperm. These cells consist of a spherical acrosomal vesicle, an amorphous cytoplasm and a distal nucleus. The results revealed that the gonopores, testis and vas deferens have the expected characteristics of the family Diogenidae, while the non-tripartite morphology of the spermatophores and the sperm follow the patterns found only in the genus Clibanarius, and the presence of the dense perforatorial ring is, to date, unique in the species of the genus, being a possible apomorphic characteristic.
\end{abstract}

KEY WORDS: Diogenidae $\cdot$ Reproduction $\cdot$ Spermatophores $\cdot$ Sperm $\cdot$ Spermiotaxonomy

\section{INTRODUCTION}

In order to understand crustacean life cycles in different habitats, it is important to have knowledge of the factors involved in their reproduction (Sastry 1983). Among decapod crustaceans, a better understanding of the relationship between female reproductive aspects and those related to male reproductive biology are necessary to complete our knowledge of the evolution of reproductive systems and the behavioral and morphological differences between the sexes (Subramoniam 1982a, Tudge 1991, 1999, Scelzo et al. 2004, Tirelli et al. 2006, Asakura 2009).

In general, the male reproductive system in decapods consists of a pair of testes and the vasa deferentia ending in openings in the coxae of the fifth pair of pereopods (gonopores). The testes and the vasa deferentia are located in the cephalothorax, with the exception of hermit crabs, which have their reproductive system allocated in the pleon, in a dorsal or lateral position (McLaughlin 1983).

The testes are responsible for producing sperm, which are packaged in spermatophores and brought to the gonopores along the vas deferens to be transferred to females (Subramoniam 1995, Hess \& Bauer 2002). The spermatophores of decapods exhibit a wide morphological diversity, with characteristics particular to members of different groups (Subramoniam 1993) and are separated into 3 general types: spherical and small spermatophores, produced by Brachyura; tubular, produced by most Macrura; and pedunculate, produced by Anomura (see Krol et al. 1992 and Tudge 2009 for reviews).

Decapod sperm also shows a great structural and morphological diversity (Subramoniam 1982b, Felgenhauer \& Abele 1991, Tudge 2009). The cells consist of an acrosomal vesicle with multiple layers, a posterior nucleus of variable density, intermediate cytoplasm 
and a variable number of arms. Among the Anomura, the acrosomal vesicle can be oblong (Jamieson 1991) or spherical (Tudge 1992, Tudge \& Scheltinga 2002) in shape and is covered by a spherical or conical operculum. Moreover, the anterior region of the cytoplasm or of the nucleus bears 3 arms that contain microtubules (Jamieson 1991).

The association of the sperm characteristics with other reproductive components (testes, vasa deferentia, and spermatophores) is important to better understand the process of fertilization (Sastry 1983, Uma \& Subramoniam 1984, Amadio \& Mantelatto 2009). In addition, the great diversity found in the morphologies of the sperm and of the spermatophore, with characteristics that are particular to members of different groups, make these structures taxonomically specific (Tudge 1991, Subramoniam 1993); thus, together with other taxonomic criteria, they can also be used to elucidate taxonomic and phylogenetic questions (Scelzo et al. 2004, Mantelatto et al. 2009, Tudge 2009).

In the superfamily Paguroidea, which contains the hermit crabs, the spermatophores are complex and tripartite structures, consisting of an ampulla, a stalk, and a pedestal (Tudge 1991, Krol et al. 1992, Subramoniam 1993, Scelzo et al. 2004, Tirelli et al. 2007, Mantelatto et al. 2009). Tripartite spermatophores with a small and spherical ampulla and a long and thin stalk have been described only for diogenid members (Tudge 1991), but exceptions in this division have been observed in some species of the genus Clibanarius, where the stalk and the pedestal are absent (Uma \& Subramoniam 1984, Hess \& Bauer 2002).

The family Diogenidae consists of 20 genera (McLaughlin et al. 2007, 2010), and to date most of the species have not had their male reproductive aspects studied. In connection with the genus Clibanarius (see references in the 'Discussion'), the male reproductive systems of only 6 genera have been described in detail: Calcinus (Tirelli et al. 2006, Amadio \& Mantelatto 2009), Dardanus (Matthews 1953), Diogenes (Tudge 1991), Isocheles (Mantelatto et al. 2009), Loxopagurus (Scelzo et al. 2004), and Strigopagurus (Tudge 1996).

Clibanarius sclopetarius (Herbst, 1796) is an intertidal hermit crab that lives on sand, mudflats and rocky substrates of beaches and mangroves, from shallow waters to a depth of $50 \mathrm{~m}$ in tropical and subtropical areas. It is found along the Atlantic coast of the Americas - Florida, Antilles, Venezuela and Guyana - and along the Brazilian coast, from Piauí to Santa Catarina (Melo 1999, F. L. Mantelatto pers. obs.). Some aspects of its biology are known from studies on larval (BrossiGarcia 1987a) and juvenile morphology (Brossi-Garcia 1987b), growth and population biology (Turra \& Leite 2000), fecundity (Turra \& Leite 2001), selection of shells (Turra 2003), intersexuality (Turra 2004), inter- specific competition (Turra \& Denadai 2004), and reproductive behavior (Turra 2005).

The present work was aimed to morphologically characterize the male reproductive system of Clibanarius sclopetarius. The morphological patterns found here were studied in context with those already described for other species of the genus, in order to provide a better understanding of the reproductive aspects of this species.

\section{MATERIALS AND METHODS}

Study area. The specimens of Clibanarius sclopetarius were collected in the Araçá region $\left(23^{\circ} 48^{\prime} 78.1^{\prime \prime} \mathrm{S}\right.$, $45^{\circ} 24^{\prime} 46.9^{\prime \prime} \mathrm{W}$ ), on the northern coast of São Paulo (Brazil). This region contains a remnant mangrove area, with halophyte vegetation that acts as a protective barrier and substrate for mollusks, crustaceans, and larvae of other organisms (Schaeffer-Novelli 1990). However, human action has modified the Araçá and reduced the numbers of mangrove trees in this area (Vergamini \& Mantelatto 2008).

Sampling and analysis. Adult males were collected throughout the intertidal region along the mud substrate of the remnant mangrove area. Live crabs were transported to the laboratory for analysis, where procedures followed the protocols by Scelzo et al. (2004, 2010), Amadio \& Mantelatto (2009), and Mantelatto et al. (2009). We selected males to cover the widest possible range of sizes.

After anesthesia by chilling, the hermit crabs were removed from their shells and measured for weight, shield length (SL) and the diameter of the gonopores. The male reproductive system was dissected from fresh specimens and was obtained by dorsally cutting the thin cuticle of the pleon. The reproductive system was observed fresh; then, it was fixed in $80 \%$ alcohol and recorded by drawing and photographs, after the vasa deferentia closest to the gonopores had been removed. The vasa deferentia were dissected, allowing observation of the spermatophores.

From the distal portion of the vas deferens of 32 hermit crabs, 10 spermatophores were measured under light microscopy. The dimensions measured were: the spermatophore's total height (TH), its average height $(\mathrm{AH})$, its total width (TW) and its lateral base width (BW) (Fig. 1).

The measurements were analyzed statistically according to Zar (1996) in the program Sigma Stat Windows, v. 2.03, using $\alpha=0.05$. Pearson's correlation was performed on spermatophore biometrics, shield length, wet weight and gonopore diameter. MannWhitney tests and Student's $t$-tests were used to check for possible differences in values of gonopore diameters. 


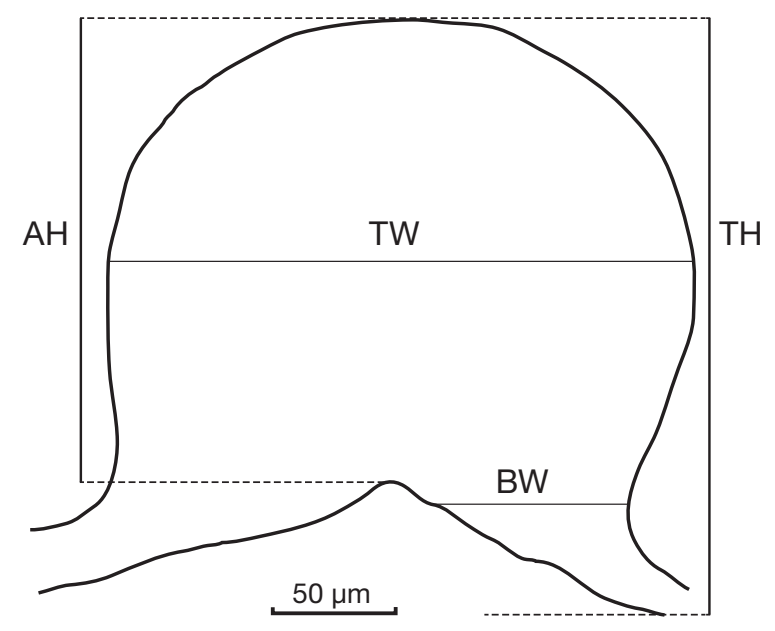

Fig. 1. Clibanarius sclopetarius. Drawing of a spermatophore showing the measurements taken: total height (TH), average height (AH), total width (TW), lateral base width (BW)

In addition to light microscopy analysis, the gonopores and spermatophores were processed for scanning electron microscopy (SEM), and the sperm was examined by transmission electron microscopy (TEM). Samples were fixed in $3 \%$ glutaraldehyde for $2 \mathrm{~h}$, followed by buffer phosphate immersion and $2 \mathrm{~h}$ fixation in 1 to $2 \% \mathrm{OsO}_{4}$ in buffer solution, with subsequent dehydration by an increasing ethanol series: 50, 70, 80, 95, and $100 \%$, for 15 min each.

SEM samples were critical-point dried using fluid $\mathrm{CO}_{2}$. They were then placed on stubs, sputter-coated with gold (Bal-tec Sputter Coater SCD050), and viewed and photographed in a scanning electron microscope (Zeiss EVO50) interfaced with a computer. TEM samples were infiltrated and embedded in EponAraldite resin, and thin sections were cut with an ultramicrotome and then transferred to small copper grids. These were contrasted with lead citrate and uranyl acetate, and photographed with a transmission electron microscope JEOL 100CX.

Voucher specimens were deposited in the Crustacean Collection of the Biology Department (CCDB) of the Faculty of Philosophy, Sciences, and Letters of Ribeirão Preto (FFCLRP), University of São Paulo, Brazil (Access Numbers: 2701 and 2702).

\section{RESULTS}

Clibanarius sclopetarius males $(\mathrm{n}=32)$ presented a reproductive system composed of a pair of testes connected by the vasa deferentia to the gonopores, located in the coxae of the fifth pair of pereopods. The SLs measured ranged from 10.50 to $26.35 \mathrm{~mm}$, with a mean of $16.46 \pm 3.79 \mathrm{~mm}$, and the wet weights ranged from 1.37 to $17.97 \mathrm{~g}$, with a mean of $5.17 \pm 3.92 \mathrm{~g}$. These variables showed positive correlation $(\mathrm{r}=0.917$; $\mathrm{p}<0.05)$.

\section{Gonopores and reproductive apparatus}

The gonopores are circular openings covered by a cuticular flap and surrounded by a few groups of simple setae (Fig. 2A). The testes are extended, white, and lobular (Fig. 2B). They are located in the central region of the pleon, in a dorsal position to the hepatopancreas, where they are juxtaposed and united. The connection to the vas deferens by collecting ducts is located in the posterior portion of each gonad. The correlation between the mean diameter of the right (RG) and left (LG) gonopores and SL was positive (LG: $r=0.84$; RG: $r=0.81 ; p<0.05)$. These were considered circular openings because there was no significant difference between the measurements of the 2 diameters of each gonopore (LG: $t=-0.882$; RG: $t=947.5$; $>$ > 0.05).

The vasa deferentia are white, cylindrical tubes. Observations of the external morphology allowed differentiation of the vas deferens into 3 regions: proximal, intermediate, and distal (Fig. 2B). The proximal region is convolute, has a diameter smaller than the other regions, and is connected to the testes. The intermediate region is coiled and more convolute than the anterior portion. The distal region does not present coils or convolutions, is the same diameter as the intermediate region, and is located in the anterior portion of the pleon, being connected to the gonopore.

\section{Spermatophore}

The spermatophore of Clibanarius sclopetarius removed from the distal portion of the vasa deferentia consists of an ampulla that packs several spermatozoa. This structure has a spherical shape in its apical portion and is lightly flattened dorso-ventrally (Fig. 3A,B). In its basal portion, each spermatophore has a central invagination and lateral projections. These projections join the ampullae, forming a spermatophore cord along the vas deferens (Fig. 4A). This cord is wrapped by mucous seminal fluid and presents convolutions into the vas deferens, starting from the intermediate region. A suture line is localized in the apical axis of each spermatophore, extending laterally on the projections (Fig. 4B). This line is formed by the walls of the spermatophore from the union of the halves of the ampulla, and its opening permits the liberation of the sperm (Fig. 4C). The correlation between the size of the spermatophores and SL was positive TH: $r=0.479$; 


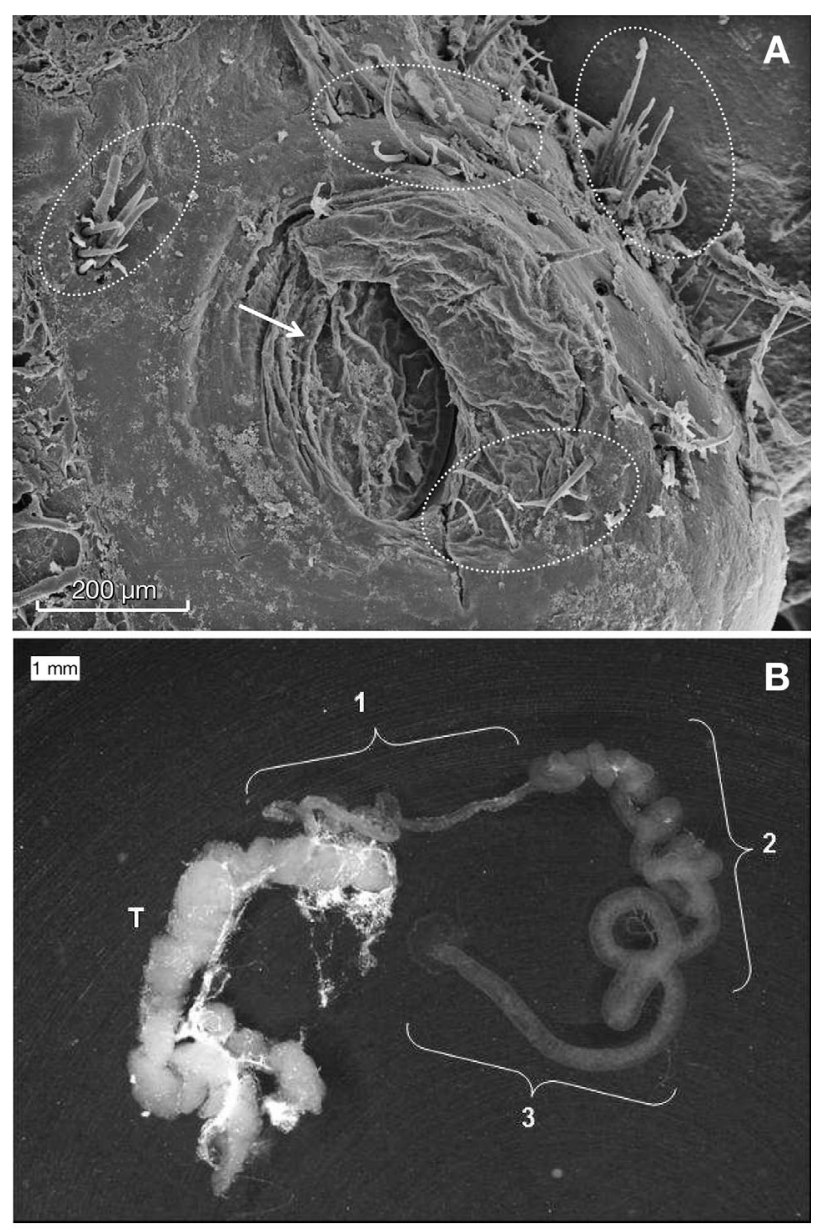

Fig. 2. Clibanarius sclopetarius. Gonopore and reproductive system of an adult male. (A) Scanning electron microscopy of the gonopore, with membranous covering (arrow); setae are enclosed by ellipses. (B) Reproductive system: testis (T), and proximal (1), inter-mediate (2), and distal (3) regions of the vas deferens

AH: $\mathrm{r}=0.452 ; \mathrm{TW}: \mathrm{r}=0.544 ; \mathrm{BW}: \mathrm{r}=0.646 ; \mathrm{p}<0.05)$ (Fig. 5).

The spermatophores show different stages of development along the vasa deferentia, beginning in the proximal portion and reaching the mature shape in the distal portion, close to the gonopores. In the proximal region, the spermatophores are molded and form a long tube where sperm appear continuously (Fig. 6A). In the intermediate portion, the spermatophores are small folds, where the sperm are separated into masses (Fig. 6B). In the distal portion, the spermatophores are morphologically mature, as described.

Among the individuals collected, 3 specimens were characterized as intersex individuals. These had gonopores in the coxae of the fifth pair of pereopods and 1 or 2 gonopores in the third pair of pereopods. Their dissection revealed the internal anatomy of the pleon to be similar to a male's, with a male reproductive
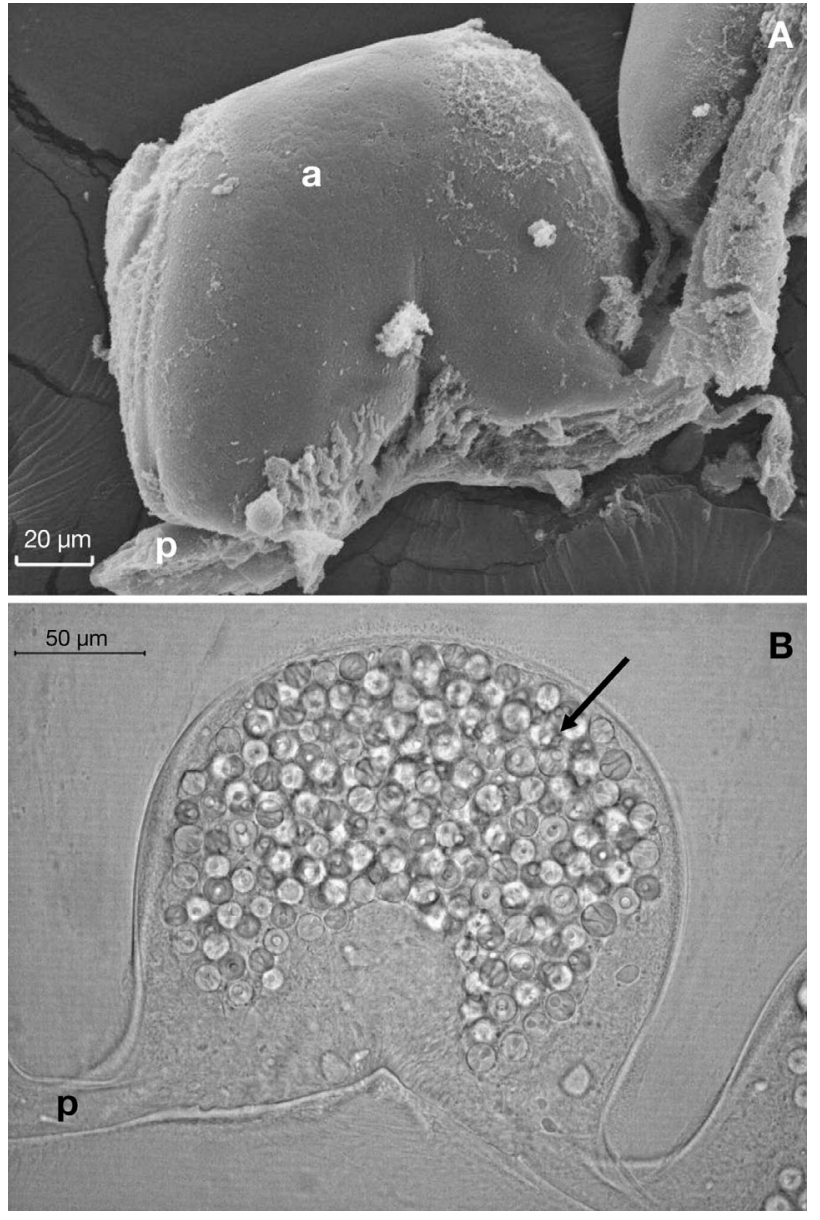

Fig. 3. Clibanarius sclopetarius. Spermatophores of the distal region of the vas deferens of an adult male. (A) Scanning electron microscopy and (B) light microscopy. a: ampulla; $\mathrm{p}$ : lateral projection; arrow indicates sperm

apparatus (testes and vasa deferentia), spermatophores, and sperm.

\section{Spermatozoon}

Observations of the sperm by TEM revealed the presence of an acrosomal vesicle above the apical axis, a posterior nucleus, and an intermediate region of cytoplasm (Fig. 7A). The acrosomal vesicle is spherical and has zones of different electron densities. The cytoplasm is amorphous and adjacent to the acrosomal vesicle; the nucleus is also amorphous.

The operculum, a thin layer of conical shape with a high electron density, is located in the most anterior portion of the acrosomal vesicle. It is followed by the subopercular zone, which extends to the central portion of the acrosomal vesicle. Adjacent are the inner 

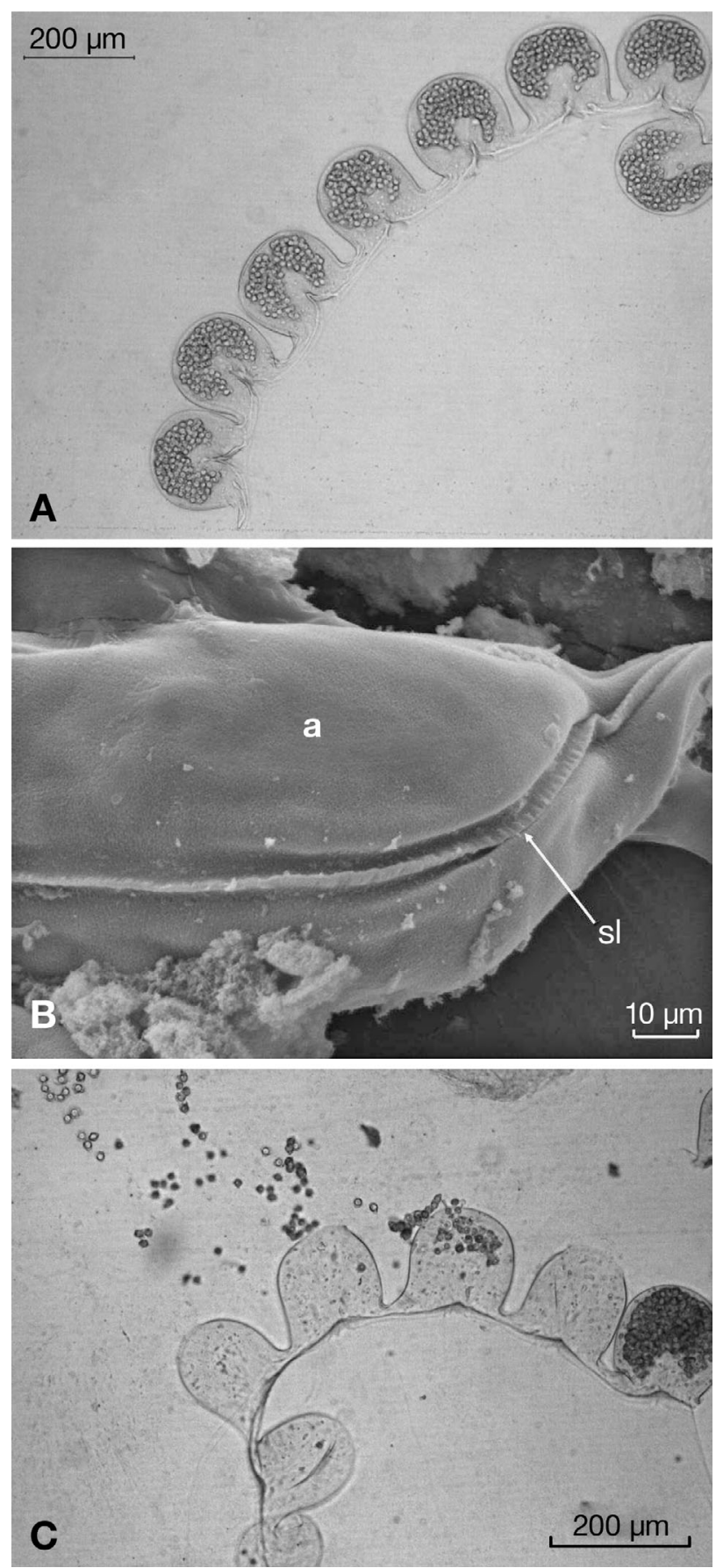

Fig. 4. Clibanarius sclopetarius. Spermatophores of the distal region of the vas deferens of an adult male. (A) Light microscopy showing the spermatophore cord. (B) Scanning electron microscopy showing the suture line. a: ampulla; sl: suture line. (C) Light microscopy showing the liberation of spermatozoa

and outer acrosomal zones, the latter being the more electron dense of the 2 zones.

The perforatorial chamber, which extends along the antero-posterior axis, is located in the center of the acrosomal vesicle. The chamber is differentiated into 2

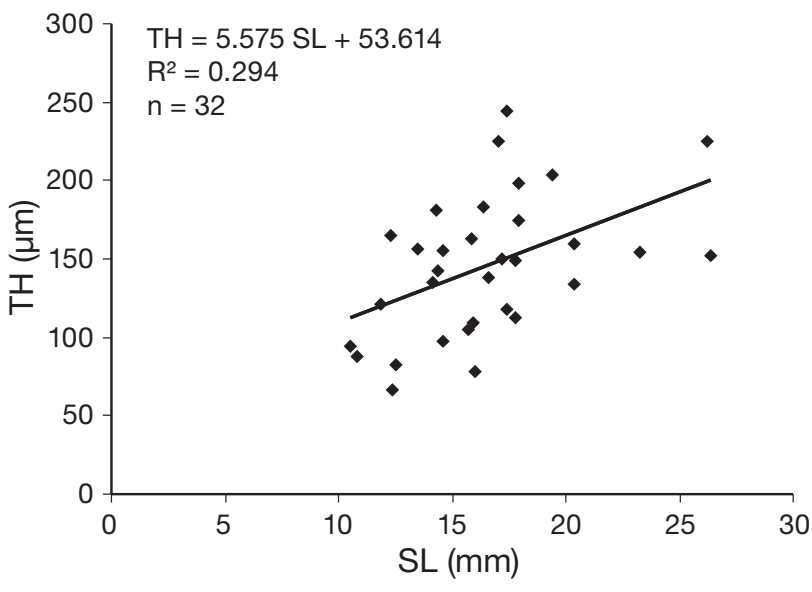

Fig. 5. Clibanarius sclopetarius. Correlation between shield length (SL) and spermatophore total height (TH)
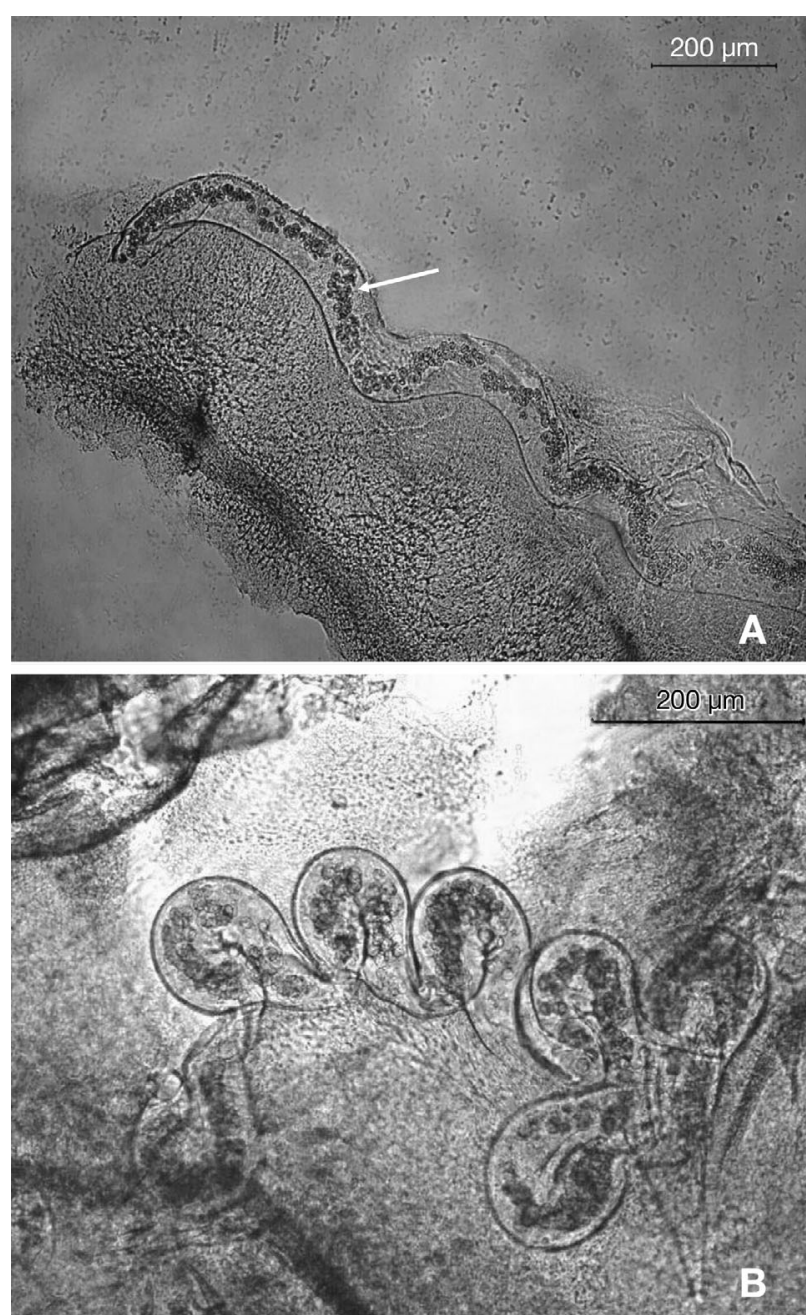

Fig. 6. Clibanarius sclopetarius. Development of the spermatophores along the vas deferens. (A) Light microscopy showing the spermatophores of the proximal region of the vas deferens; arrow indicates continuous tube with spermatozoa. (B) Light microscopy showing the spermatophores of the intermediary region of the vas deferens 

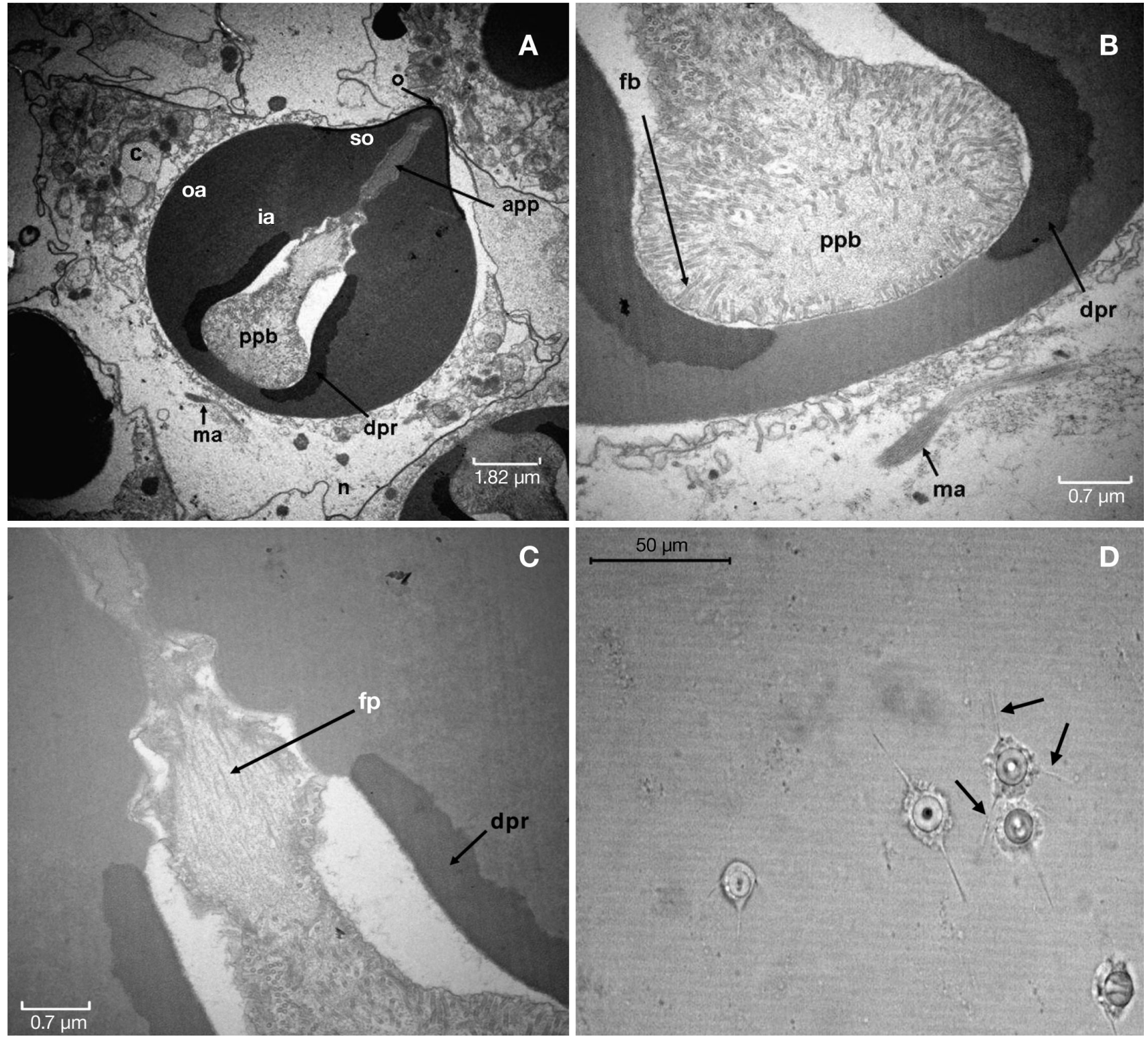

Fig. 7. Clibanarius sclopetarius. Spermatozoon. (A,B,C) Transmission electron microscopy showing anterior perforatorial projection (app), dense perforatorial ring (dpr), fibers of bulb (fb), fibers of perforatorial projection (fp), inner acrosome zone (ia), microtubule of the arm (ma), region of cytoplasm (c), region of nucleus (n), operculum (o), outer acrosome zone (oa), posterior perforatorial bulb (ppb) and subopercular zone (so). (D) Light microscopy; arrows indicate arms of the spermatozoon

continuous parts, a posterior bulb and an anterior projection. This projection is surrounded by the subopercular zone and contains longitudinal fibers that extend to the operculum (Fig. 7C). In the bulb, the fibers are short projections that extend to the center (Fig. 7B). In the posterior portion of acrosomal vesicle, an electrondense zone surrounds the bulb; this zone is the perforatorial ring (Fig. 7B). The cytoplasm contains spherical vesicles, but the limitation of the nucleus is not visible. However, it is probably located where the microtubules support the 3 arms of the cell (Fig. 7D).

\section{DISCUSSION}

Together with the present results for Clibanarius sclopetarius, the spermatophore morphology of diogenid hermit crabs has now been described for 10 genera and 24 species (see Mantelatto et al. 2009 for a review). The present study provides a second description of spermatophore morphology and morphometry for hermit crabs of the genus Clibanarius from the Atlantic coast.

Clibanarius sclopetarius does not have a modified copulatory structure in its gonopores or pleopods, such 
as in other families and infraorders (Tudge \& Lemaitre 2004). The cuticular flap that covers the genital openings was the only structure observed and may function to protect the spermatophores from the external environment, since the intertidal area is subject to instability and physical stress. During low tide, hermit crabs are susceptible to factors pertaining to the aerial environment, such as desiccation (Grant \& McDonald 1979). This cuticular flap has also been observed in other intertidal diogenids, such as Calcinus tibicen (Amadio \& Mantelatto 2009), Clibanarius erythropus (Tirelli et al. 2007), and C. vitattus (Hess \& Bauer 2002).

Each genital opening is connected to its respective testis through a vas deferens, a long tube with folds and convolutions. This appears to be common in the family Diogenidae and has been observed in other genera as well (Amadio \& Mantelatto 2009). The 3 distinct regions (proximal, intermediary, and distal) found in the tubes are associated with external observation, and with the different phases of the spermatophores' development.

Further regions of the vas deferens can be differentiated by using techniques that allow the identification of the organ's different functional regions (Matthews 1953). These are characterized by distinct epithelial cells, the function of which could be, for instance, the secretion of seminal liquid (Subramoniam 1995). The characterization of these regions is associated with the spermatophore's development. According to Krol et al. (1992), the regional differences in the vas deferens may be related to the type of spermatophore produced by the species, as those resulted from secretor-type cells and contractions of the muscles adjacent to the vas deferens (Matthews 1953).

In the case of Clibanarius sclopetarius, the lack of stalk and foot in the spermatophore could be related to the lack of cells that secrete material for the formation of these parts. This characteristic is possibly related to the mechanism of spermatophore transfer from males to females and to the environment in which they live (Uma \& Subramoniam 1984). However, only histological analyses would be able to show the epithelial cells of the vasa deferentia and their secretion.

The morphological pattern of the spermatophore in Clibanarius sclopetarius described above differs from that of other Diogenidae because most of the diogenid genera have spermatophores with ampullae, stalks, and feet. The non-pedunculate spermatophore is a characteristic of the infraorder Brachyura and of other Decapoda families, while, in the superfamily Paguroidea (Anomura), spermatophores present a more complex structure, being tripartite (Krol et al. 1992). However, in the genus Clibanarius, in spite of the nontripartite spermatophore, the shape of the ampulla follows the morphology of the ampullae described for Dio- genidae (see Tudge 1991, Tirelli et al. 2007). Therefore, it can be speculated that the lack of a stalk in some species of Clibanarius is a secondary loss in the genus. Future studies of the spermatophores of this family could reveal new patterns for Clibanarius and other genera that still remain poorly studied with respect to male reproductive characteristics, and may be important in order to conduct a more robust discussion of the evolutionary history of the genus Clibanarius and the family Diogenidae, using these reproductive aspects.

The non-tripartite pattern has also been noted for the species Clibanarius longitarsus (De Haan, 1849) (Uma \& Subramoniam 1984) and C. vitattus (Hess \& Bauer 2002). This characteristic set C. sclopetarius in a closer phylogenetic relationship with these 2 species than with others that have pedunculate spermatophores, such as C. erythropus (Latreille, 1818) (Tirelli et al. 2007), C. misanthropus (Risso, 1826) (Mouchet 1931), C. virescens (Krauss, 1843) (Tudge 1991), and C. corallinus (Milne Edwards, 1848) (Tudge 1991). Given the additional analyses and studies of the spermatophores of other species, this proposition can be tested.

Scelzo et al. (2004) suggested that biometric measurements of spermatophores could, in some cases, be used to distinguish between the species of a family. The biometric analysis of the spermatophores of Clibanarius sclopetarius in the present study showed positive correlation with SL, indicating a directly proportional relation to growth, similar to findings in Loxopagurus loxochelis (Scelzo et al. 2004), Calcinus tibicen (Amadio \& Mantelatto 2009), and Isocheles sawayai (Mantelatto et al. 2009). These results suggest that the spermatophore size cannot be used as a character of identification if the values found are directly associated with the individual size. Furthermore, the fact that C. sclopetarius spermatophores are non-pedunculate limits a comparison with species that have a pedunculate spermatophore, since the different morphologies of this structure surely promote differences in biometry. We strongly suggest the establishment of a standard code of measurements in hermit crabs to facilitate comparisons. In addition, and considering that individual body size strongly influences spermatophore size, Fantucci \& Mantelatto (2011) suggest that more attention be given to morphology than to size, to avoid possible errors in comparisons.

Knowledge on the biology of intersex individuals is very limited (Gusev \& Sabotin 2007), with most studies only reporting their rare occurrence. The lack of information on spermatophore morphology has been discussed by Mantelatto et al. (2009). The present study is the first examination of spermatophore structure in intersex individuals. Despite the presence of female and male gonopores in intersex individuals of Clibanarius sclopetarius, the morphology of the reproductive apparatus and the spermatophores allows us to 
conclude that these individuals, in the present morphotype, are functional males. This observation is corroborated by their reproductive behavior - including successful fertilization - which, according to Turra (2005), is compatible with that of normal males. An analogous condition was proposed for intersex individuals of the diogenid Isocheles sawayai by Fantucci et al. (2008). Recently, Sant'Anna et al. (2010) observed that a certain percentage of intersex individuals of the congener C. vitattus also developed functional male and female gonads in the same individual, indicating that intersex hermit crabs can reproduce as either males or females. This can be a true sequential hermaphroditic process.

Intersexuality may be caused by factors related to genetics, to the environment, or to parasitism (Bulnheim 1978). For Coenobita rugosus (Milne-Edwards, 1837), it was suggested that additional female openings occurred as a result of endocrine abnormality (Gusev \& Sabotin 2007). For the intersex specimens of Clibanarius sclopetarius collected at Araçá Beach in our study, a possible influence of environmental factors, such as the pollution (Ford et al. 2004), cannot be disregarded. Similar has been postulated for Clibanarius vitattus by Sant'Anna et al. (2010). The abovementioned region suffers constant anthropogenic degradation through sewage discharge and petroliferous ducts (Tominaga et al. 2006). Thus, it is imperative to conduct more studies on the factors involved in the development of the genital opening in intersex individuals in order to better understand this mechanism.

Our observations of the sperm of Clibanarius sclopetarius fit the patterns that have already been described for the infraorder Anomura, i.e. the presence of $3 \mathrm{arms}$ and a spherical acrosome vesicle with conical electrondense operculum projected to the cytoplasm (Jamieson 1991). On the other hand, the presence of the dense perforatorial ring is, up to now, a unique characteristic for the species of this genus, which is possibly an apomorphic characteristic, and could allow differentiation of the genus Clibanarius from other species (see Tudge 1997). Consequently, it is expected to play an important role in future studies of the phylogenetic relationships in the family Diogenidae. The shape of the perforatorial chamber and the extension of the cytoplasm, as described here for the sperm of C. sclopetarius, are also considered by Tudge (1992) to be characteristics that distinguish the genus Clibanarius.

Among the congener species with described spermatozoa, only Clibanarius erythropus (Tudge \& Justine 1994) does not have a spherical, acrosomal vesicle, which makes this species unique. In other congener species, distinctions can be made more reliably by determination of the origin of the arms, the components of the cytoplasm, and the shape of the operculum (Tudge 1992, 2009).
The present study confirms that the reproductive system of Clibanarius sclopetarius, composed of paired testes and vasa deferentia, has characteristics expected in the superfamily Paguroidea. The spermatophores and sperm, however, have morphological characteristics found only in the genus Clibanarius. However, this is a rather large genus with 59 species worldwide (Mantelatto et al. 2010, McLaughlin et al. 2010), so the available knowledge concerning the morphology of the spermatophore in only 8 species (including the present work) may not represent its complete diversity; thus, future studies are encouraged to improve our understanding of the phylogeny and evolution of members of the diverse Diogenidae family.

Acknowledgements. The present study was part of a bachelor's thesis by N.M.S. and was supported by a scientific fellowship from Conselho Nacional de Desenvolvimento Científico e Tecnológico. F.L.M. is grateful to CNPq (Proc. 301359/2007$5 ; 302748 / 2010-5)$ and Fundação de Amparo à Pesquisa do Estado de São Paulo (FAPESP) (Proc. 2010/50188-8) for a research fellowship and grant support, respectively. Special thanks to those who collaborated during the course of this study: to the Laboratory of Electron Microscopy, Department of Cellular and Molecular Biology and Pathogenic Bioagents, Faculty of Medicine of Ribeirão Preto/USP, especially to Maria Dolores Seabra Ferreira and José Maulin for the preparation of the biological samples for electron microscopy and TEM analysis and image capture; to the Laboratory of Scanning Electron Microscopy and Microanalysis, Department of Chemistry, FFCLRP/USP, especially to Dr. Rodrigo Ferreira Silva for SEM analysis and image capture; to the Postgraduate Program in Comparative Biology of FFCLRP/USP and the Centro de Biologia Marinha (CEBIMar/USP) for support; to Álvaro da Silva Costa and the members of the Laboratory of Bioecology and Crustacean Systematics of FFCLRP/USP for help during field and laboratory work, and to Ivana Miranda, Mariana Terossi, Dalton Amorim, and Fernando Zara for suggestions during the thesis defense of N.M.S. and on an earlier version of the manuscript. We also thank the anonymous reviewers for their suggestions and contributions toward improving this paper, and Julia Hetem and the editorial committee for English revisions. All experiments conducted during the present study complied with the currently applicable state and federal laws of Brazil.

\section{LITERATURE CITED}

Amadio LM, Mantelatto FL (2009) Description of the male reproductive system of the hermit crab Calcinus tibicen (Decapoda: Anomura: Diogenidae). J Crustac Biol 29: $466-475$

Asakura A (2009) The evolution of mating systems in decapod crustaceans. In: Martin JW, Crandall KA, Felder DL (eds) Decapod crustacean phylogenetics. CRC Press, New York, NY, p 121-182

Brossi-Garcia A (1987a) Morphology of the larval stages of Clibanarius sclopetarius (Herbst, 1796) (Decapoda, Diogenidae) reared in the laboratory. Crustaceana 52:251-275

Brossi-Garcia A (1987b) Juvenile development of Clibanarius sclopetarius (Herbst, 1796) (Crustacea: Paguridea: Diogenidae), in the laboratory. J Crustac Biol 7:338-357 
Bulnheim HP (1978) Interaction between genetic, external, and parasitic factors in sex determination of the crustacean amphipod Gammarus duebeni. Helgol Meeresunter 31: 1-33

Fantucci MZ, Mantelatto FL (2011) Male reproductive apparatus and spermatophore morphology of the hermit crabs Pagurus brevidactylus and Pagurus criniticornis (Anomura, Paguridae). J Morphol (in press) doi: 10.1002/jmor.10987

Fantucci MZ, Biagi R, Mantelatto FL (2008) Record of intersexuality in the western Atlantic hermit crab Isocheles sawayai (Anomura: Diogenidae). Mar Biodiv Rec 1:1-3

Felgenhauer BE, Abele LG (1991) Morphological diversity of decapod spermatozoa. In: Bauer RT, Martin JW (eds) Crustacean sexual biology. Columbia University Press, New York, NY, p 322-341

Ford AT, Fernandes TF, Rider SA, Read PA, Robinson CD, Davies IM (2004) Endocrine disruption in a marine amphipod? Field observations of intersexuality and de-masculinisation. Mar Environ Res 58:169-173

Grant J, McDonald J (1979) Desiccation tolerance of Eurypanopeus depressus (Smith) (Decapoda: Xanthidae) and the exploitation of microhabitat. Estuaries 2:172-177

Gusev O, Sabotin Y (2007) Observation of intersexuality in land hermit crabs (Anomura: Coenobitidae). J Mar Biol Assoc UK 87:533-536

Hess GS, Bauer RT (2002) Spermatophore transfer in the hermit crab Clibanarius vittatus (Crustacea, Anomura, Diogenidae). J Morphol 253:166-175

Jamieson BGM (1991) Ultrastructure and phylogeny of crustacean spermatozoa. Mem Queensl Mus 31:109-142

Krol RM, Hawkins WE, Overstreet RM (1992) Reproductive components. In: Harrison FW (ed) Microscopic anatomy of invertebrates, Decapoda, Crustacea, Vol 10. Wiley-Liss, New York, NY, p 295-343

Mantelatto FL, Scelzo MA, Tudge CC (2009) Morphological and morphometric appraisal of the spermatophore of the southern hermit crab Isocheles sawayai Forest and Saint Laurent, 1968 (Anomura: Diogenidae), with comments on gonopores in both sexes. Zool Anz 248:1-8

Mantelatto FL, Fernandes-Góes LC, Fantucci MZ, Biagi R, Pardo LM, de Góes JM (2010) A comparative study of population traits between two South American populations of the striped-legged hermit crab Clibanarius vittatus. Acta Oecol 36:10-15

Matthews DC (1953) The development of the pedunculate spermatophore of a hermit crab, Dardanus asper (De Haan). Pac Sci 7:255-266

McLaughlin PA (1983) Internal anatomy. In: Mantel LH (ed) The biology of Crustacea, Vol 5. Academic Press, New York, NY, p 1-41

McLaughlin PA, Lemaitre R, Sorhannus U (2007) Hermit crab phylogeny: a reappraisal and its 'fall-out'. J Crustac Biol 27:97-115

McLaughlin PA, Komai T, Lemaitre R, Rahayu DL (2010) Annotated checklist of anomuran decapod crustaceans of the world (exclusive of the Kiwaoidea and families Chirostylidae and Galatheidae of the Galatheoidea) Part ILithodoidea, Lomisoidea and Paguroidea. Raffles Bull Zool 23(Suppl):5-107

Melo GAS (1999) Manual de identificação dos Crustacea Decapoda do litoral brasileiro: Anomura, Thalassinidea, Palinuridea, Astacidae. Editora Plêiade, São Paulo

Mouchet S (1931) Spermatophores des Crustacés Décapodes Anomoures et Brachyoures et castration parasitaire chez qualques Pagures. Ann Stat Oceanogr Salambo 6:1-210

Sant'Anna BS, Turra A, Zara FJ (2010) Simultaneous activity of male and female gonads in intersex hermit crabs. Aquat
Biol 10:201-209

Sastry AN (1983) Ecology aspects of reproduction. In: Vernberg FJ, Vernberg WB (eds) The biology of Crustacea. Academic Press, New York, NY, p 179-270

Scelzo MA, Mantelatto FL, Tudge CC (2004) Spermatophore morphology of the endemic hermit crab Loxopagurus loxochelis (Anomura, Diogenidae) from the southwestern Atlantic-Brazil and Argentina. Invertebr Reprod Dev 46: $1-9$

Scelzo MA, Fantucci MZ, Mantelatto FL (2010) Spermatophore and gonopore morphology of the southwestern Atlantic hermit crab Pagurus exilis (Benedict, 1892) (Anomura, Paguridae). Zool Stud 49:421-433

Schaeffer-Novelli Y (1990) Variability of mangrove ecosystems along the Brazilian coast. Estuaries 13:204-218

Subramoniam T (1982a) In vitro observation on sperm morphology in a few decapod crustaceans. In: Subramoniam T (ed) Manual of research methods for marine invertebrate reproduction, Vol. 9. Central Marine Fisheries Research Institute, Kochi, p 83-88

Subramoniam T (1982b) A morphological investigation on the spermatophores of selected crustaceans. In: Subramoniam $\mathrm{T}$ (ed) Manual of research methods for marine invertebrate reproduction, Vol. 9. Central Marine Fisheries Research Institute, Kochi, p 93-98

Subramoniam T (1993) Spermatophores and sperm transfer in marine crustaceans. In: Blaxter JHS, Southward AJ (eds) Advances in marine biology. Academic Press, New York, NY, p 129-214

Subramoniam T (1995) Light and electron microscopic studies on the seminal secretions and the vas deferens of the penaeiodean shrimp, Sicyonia ingentis. J Biosci 20:691-706

Tirelli T, Campantico E, Pessani D, Tudge CC (2006) Description of the male reproductive apparatus of the hermit crab Calcinus tubularis (Decapoda: Anomura: Diogenidae). Crustac Res 6:13-21

- Tirelli T, Campantico E, Pessani D, Tudge CC (2007) Reproductive biology of Mediterranean hermit crabs: male reproductive apparatus of Clibanarius erythropus Decapoda Anomura). J Crustac Biol 27:404-410

Tominaga EN, Rugno NC, Flynn MN (2006) Processos hidrodinâmicos e sedimentares avaliados na região de São Sebastião, SP. In: Proc Env Health World Congress, Santos, p 671-675

Tudge CC (1991) Spermatophore diversity within and among the hermit crab families, Coenobitidae, Diogenidae, and Paguridae (Paguroidea, Anomura, Decapoda). Biol Bull 181: 238-247

Tudge CC (1992) Comparative ultrastructure of hermit crab spermatozoa (Decapoda: Anomura: Paguroidea). J Crustac Biol 12:397-409

Tudge CC (1996) Spermatophore morphology and spermatozoal ultrastructure of the recently described hermit crab, Strigopagurus boreonotus Forest, 1995 (Decapoda, Anomura, Diogenidae). Bull Mus Natl Hist Nat 18:547-555

Tudge CC (1997) Phylogeny of the Anomura (Decapoda, Crustacea): spermatozoa and spermatophore morphological evidence. Contrib Zool 67:125-141

> Tudge CC (1999) Spermatophore morphology in the hermit crab families Paguridae and Parapaguridae (Paguroidea, Anomura, Decapoda). Invertebr Reprod Dev 35:203-214

Tudge CC (2009) Spermatozoal morphology and its bearing on decapod phylogeny. In: Martin JW, Crandall KA, Felder DL (eds) Decapod crustacean phylogenetics. CRC Press, New York, NY, p 101-119

Tudge CC, Justine JL (1994) The cytoskeletal proteins actin and tubulin in the spermatozoa of four decapod crabs 
(Crustacea, Decapoda). Acta Zool 75:277-285

Tudge C, Lemaitre R (2004) Studies of male sexual tubes in hermit crabs (Crustacea, Decapoda, Anomura, Paguroidea). I. Morphology of the sexual tube in Micropagurus acantholepis (Stimpson, 1858), with comments on function and evolution. J Morphol 259:106-118

Tudge CC, Scheltinga DM (2002) Spermatozoal morphology of the freshwater anomuran Aegla longirostri BondBuckup, 1994 (Crustacea: Decapoda: Aeglidae) from South America. Proc Biol Soc Wash 115:118-128

Turra A (2003) Shell condition and adequacy of three sympatric intertidal hermit crab populations. J Nat Hist 37:1781-1795

Turra A (2004) Intersexuality in hermit crabs: reproductive role and fate of gonopores in intersex individuals. J Mar Biol Assoc UK 84:757-759

Turra A (2005) Reproductive behavior of intertidal hermit crabs (Decapoda, Anomura) in southeastern Brazil. Rev Bras Zool 22:313-319

Turra A, Denadai MR (2004) Interference and exploitation

Editorial responsibility: Victor Meyer-Rochow, Bremen, Germany components in interspecific competition between sympatric intertidal hermit crabs. J Exp Mar Biol Ecol 310: 183-193

- Turra A, Leite FPP (2000) Population biology and growth of three sympatric species of intertidal hermit crabs in southeastern Brazil. J Mar Biol Assoc UK 80:1061-1069

Turra A, Leite FPP (2001) Fecundity of three sympatric populations of the hermit crabs (Decapoda, Anomura, Diogenidae). Crustaceana 74:1019-1027

Uma K, Subramoniam T (1984) A comparative study of the spermatophore in Scylla serrata (Forskal) (Decapoda Brachyura) and Clibanarius longitarsus (De Haan) (Decapoda Anomura). J Mar Biol Assoc India 26:103-108

Vergamini FG, Mantelatto FL (2008) Microdistribution of the juveniles and adults of the mud crab Panopeus americanus (Brachyura, Panopeidae) in a remnant mangrove area in the Southwest Atlantic. J Nat Hist 42:1581-1589

Zar JH (1996) Biostatistical analysis. Prentice-Hall, Engelwood Cliffs, NJ

Submitted: November 22, 2010; Accepted: April 4, 2011

Proofs received from author(s): May 30, 2011 